\title{
Annemarie Steidl, On Many Routes: Internal, European, and Transatlantic Migration in the Late Habsburg Empire \\ West Lafayette, Indiana, Purdue University Press, 2021, 344 pp.
}

Simplistic notions of understanding human mobility have long burdened migration studies. Often, such notions relied on categorizations imported from state apparatuses. As a result, migration scholars have treated human movements in a binary and exclusive fashion, dividing between seasonal and permanent, legal and illegal, and most notably between internal and international migration. Building on recent scholarship that has challenged these shortcomings, in her most recent book, Annemarie Steidl draws on the area of the Habsburg Empire to demonstrate the complex and multifaceted character of migrations. Steidl, a distinguished migration scholar and professor at the Department of Social and Economic History at the University of Vienna, has chiefly applied quantitative analysis to explain migration history in her numerous publications.

Similarly, On Many Routes relies on quantitative methods. It examines Habsburg population censuses to display the complexity of movements within the Habsburg Empire as well as the relocations to European and transoceanic destinations. Steidl convincingly argues that migration patterns were much more entangled and interdependent than migration scholarship has traditionally believed. Therefore, transatlantic, European, and intra-Habsburg migrations were, in reality, not separate phenomena but, rather, interconnected movements. While transatlantic migrations have long been at the center of attention of migration scholars, they represent only a portion of the diverse mobilities that Central Europeans pursued in the nineteenth century. Steidl argues that it was much more common for a subject of the Habsburg Empire to move shorter distances than to take part in European or transoceanic migrations. The perception of mobility has been distorted, however, mainly due to the naturalization of the nation-state perspective. In line with current scholarship, therefore, Steidl proposes to reframe migrations within regional frameworks. She argues that migrations in the late nineteenth century were regionally rather than state dependent. Regions, such as Voralberg extending to Baden and Württemberg to the north, St. Gallen to the west and Trentino and part of Veneto to the south, represented socio-economic frameworks catering to humans' needs and expectations. In addition, rather than perceiving migrations as definite departures and arrivals, Steidl proposes to examine movements going back-and-forth, therefore not having a definite end in the point of destination.

Movements going back-and-forth are a thread linking diverse mobilities presented in the book. While Steidl devotes the first chapter to the study of migrations within Imperial Austria and the Kingdom of Hungary, she approaches inter-European mobilities in the second. In the third, she moves on to explore transatlantic migrations. In the fourth, she juxtaposes and compares all types of movements to find new modes of understanding human mobility. In presenting "internal" migrations, 
Steidl sheds light on various forms of mobilities that were present in the area of the Habsburg Empire since the early modern period. As evident from the ambition of her book, Steidl attempts to bridge the gap separating the knowledge of preindustrial artisan migration with the one focusing on nineteenth-century mass migration. She finds that the people of Imperial Austria were constantly crisscrossing the territory. However, the available data prevented her from analyzing movements occurring within the same administrative units and between villages and small towns (31). The state controlled the movements by the right of domicile, Heimatrecht; registered by the local community and acquired by birth, marriage, or residence in the community for ten (later four) years. The instrument of Heimatrecht, therefore, facilitated the research of migrations on longer distances.

These movements were often caused by striking economic imbalances within Imperial Austria. By 1900, Austria was one of the most economically inhomogeneous states on the European continent (12). Migrations to industrializing and mining centers, such as those in Lower Austria, northern Bohemia and northern Styria, were widespread. Most migrants came from the surrounding districts and closer crownlands. In contrast, this type of internal migration was far less typical in the Austrian east and south, in the provinces of Galicia, Bukovina, Dalmatia, Croatia, Slavonia, and Carniola, where migrants chose different destinations, most often to other European states (34). Movements to industrializing centers were not permanent but instead formed part of a pattern of moving back-and-forth. Therefore, Steidl challenges the assumption that the population growth of urban centers was owed to rural exodus. Instead, she examines urbanization in the light of complementarity between towns and the countryside. Most moves to urban agglomerations, she argues, were temporary. Work in towns formed part of the rural-urban life cycle rather than the beginning of a permanent settlement. Likewise, Steidl believes the growth of the urban population did not owe as much to immigration from the countryside as it did to endogenous population growth and migrations from other cities (48). Examining population growth in Habsburg cities, she claims that only Vienna attracted migrants from the entire empire, while the other cities, even Trieste, predominantly pulled migrants from the surrounding provinces.

Movements from the Habsburg Empire to other European states still await to be properly researched. Thorough inquiry is, however, difficult since Austrian authorities were not much concerned with movements crossing national borders. Hungarian offices, on the other hand, were more diligent in collecting data regarding their citizens. In addition, insufficient data provided by the censuses prevented Steidl from capturing a more detailed image of migratory movements. As censuses were recorded on December 31, they did not entail seasonal migrants, which were very numerous. Only the German Reich, the largest employer of the Austro-Hungarian workforce, attracted around two million Polish Galician seasonal workers each year. As migrations began to unfold in the 1870 s, the Reich did not perceive the immigrants as a threat to its stability but considered them a driving force of its economy. 
Yet, from the 1880s on, when migration increased, the "Polish question" began to concern the German public. As a result, the Reich expelled Polish-speaking Austrian and Russian citizens. However, from 1890, it allowed them to travel seasonally to support the Reich's agriculture. The seasonal pattern transformed with the outbreak of the war. At that time, the German Reich closed its borders and obliged Polishspeaking Galicians to work for the armaments industry (84). While Polish migrations to Germany are well known in migration history, Steidl demonstrates that they were not a straightforward response to the Reich's economic development.

Initially, Polish-speaking Galicians moved to Silesia, the territory of Poznan and Saxony and dispersed only gradually across Prussia $(76,77)$. Likewise, Bohemians commuted to nearby Saxony to work in the garment industry and construction. Notwithstanding the economic success of Bohemian lands - Bohemia represented the industrial center of the Habsburg Empire - the out-migration from the territory outnumbered the immigration (74). Conversely, the industrializing Alpine region of Voralberg experienced population growth, owing largely to immigration. Its booming textile industry primarily attracted Italian-speaking female migrants from the nearby district of Trento, Italian-speaking Swiss districts and the Kingdom of Italy. The number of Italian laborers was so high that the local Socialist party in Bregenz held political meetings in Italian. Furthermore, Bregenz was also a hub for Italian transmigrants who traveled further to German and Swiss regions. The local railway station had a special waiting room, also known as Italiener-Halle (99).

By the end of the nineteenth century, the burgeoning American economy pulled millions of immigrants, triggering flows that captured the European imagination. Mass migrations came to be associated with transatlantic travel. However, as Steidl demonstrates, transatlantic migrations were not a novelty but rather an extension of the established European routes. Furthermore, transatlantic migrations did not dramatically diminish European movements. Emigration from the Habsburg Empire to the USA acquired massive proportions after the economic downturn of 1890. At that time, centers of transatlantic migrations were transferred to the European south and east, specifically to the Kingdom of Italy, the Russian Empire and Austria-Hungary. While in the mid-nineteenth century, mostly Habsburg Germans and Czechs were involved in transatlantic travel, half a century later, masses of South Slavs and Galicians began to take part in transoceanic migration. Steidl points out that whereas the period of mass migration received scholarly attention, the role of preceding movements and pioneers has been largely overlooked. Corroborating her findings by explaining migrations from Voralberg and Bohemian lands, she claims that the Habsburg pioneers derived either from areas with established migration networks or from industrial centers. Voralberg's laborers and artisans had been on the move from the seventeenth century on, seeking employment in neighboring Grand Duchy of Baden, Duchy of Württemberg, Swiss St. Gallen, and up to Luxembourg and the Netherlands. The first transatlantic migrants from Voralberg comprised skilled artisans, masons, quarrymen, and carpenters who left their homes during the economic 
boom period (126). The Bohemian lands, Steidl argues, were from very early on linked to neighboring German lands of Saxony, Prussia, and Bavaria. The networks they established on German soil would later be extended to transatlantic connections. The major outflow of Bohemians toward the USA took place after the revolution of 1848. Unlike the other Slavs who followed from 1880, Bohemians traveled with their families and settled in the American countryside. As the center of migrations moved to Galicia and the triangle between Trieste, Zagreb, and Split, migrants preferred to find a job in the expanding American industry. Notwithstanding the distances, these migrants were more likely to travel back-and-forth than the rural ones. Therefore, Steidl argues that temporary moves across the ocean continued the tradition of seasonal migrations and formed part of similar household strategies (152).

Steidl especially highlights the issue of return migration, which migration scholars have often neglected. Even though it is difficult to find out how many migrants indeed returned, she claims that most of the emigrants traveling overseas between 1900 and 1914 did not consider settling permanently in the USA. Migration decisions were mostly embedded in social relations and were not dependent on statesponsored activities. As a result, state-directed repatriation campaigns were often in vain. Such was the case of the campaign led by the Kingdom of Hungary, a state that devised migration policies to create a nationally homogenous nation-state (154). However, even when relatives expected their family members to return, repatriation was not an easy and straightforward move "home". The migrants' native neighborhoods often looked at potential "newcomers" with suspicion. Not only the skills and experiences but also their habits and attitudes were frequently considered to be harmful to social stability. Inspired by local priests as well as by authorities who were skeptical of innovative production methods, local communities were often unwelcoming to returnees. Not surprisingly, in Galicia, returnees from the Reich were often despicably called chuligani pruscy, while the slightly less offensive label amerykanie was attached to those who repatriated from the USA (160).

By building on the argument that transatlantic migrations formed but a part of a complex network of interrelated migrations, in the last chapter, Steidl works on developing a more persuasive display of human mobility. Migration scholarship has long been beset by "binaries," among which the division between internal and international migrations has been the most persistent. Yet, the difference between internal and international is, as Steidl points out, far from clear. She demonstrates the artificiality of division with the example of Polish Galicians who traveled to nearby German Katowice to work in mines. At the same time, Slovenian- and Italian-speaking construction workers walked hundreds of kilometers without passing the state border to work in Vienna. As Steidl argues concerning the internal-international divide, the main issue concerning migration scholarship should be whether migrants recognized cultural differences between moving to a town just across the state border or to another place within the same state (164). 
Furthermore, as migration patterns were incredibly entangled and interrelated, she considers it myopic to focus solely on certain types of migrations. Consequently, studies that have focused on a single part of the whole story have often resulted in biased explanations (215). Moreover, contrary to simplistic interpretations which explained migrations as responses to structural necessities, Steidl demonstrates that Central Europeans were not constrained in their migration behavior. As she shows in the case of Galicia, migrants were not pushed toward specific destinations but could instead choose between different opportunities. Neither did migrants always follow their kin. While some of them chose places familiar to their relatives, others went to areas not settled by their acquaintances. Therefore, many, but certainly not all, emigrants practiced chain migration (209).

Steidl does not propose new theoretical concepts to explain human mobility. Instead, she opts for a nuanced and complex reading of migration processes, acknowledging the interrelated and entangled character of movements. In doing so, she demonstrates the continuity of previous movements in mass migrations of the late nineteenth century. The fact that she managed to integrate knowledge separating previous forms of migrations from the movements which have traditionally attracted migration scholars undoubtedly merits historians' attention. Her innovative approach owes largely to recent migration scholarship, which has challenged simplistic categorizations that divided the field and produced partial images of human mobility. Therefore, questioning traditional scholarly assumptions, Steidl persuasively demonstrates that migrations are among the most complex human phenomena. Yet, even though she is undoubtedly correct in displaying how categorizations imported from state bureaucracies distort the image of migrations, the usage of some form of categories seems to be inevitable for scholarly work. Nevertheless, her approach provides an invaluable contribution to migration studies and will remain an important work to consider when addressing mobility, particularly but not only in the Central European area. 